\title{
BLOOD AGGLUTININS IN RELATION TO BLOOD TRANSFUSION
}

\author{
By C. J. C. BRITTON, M.D., D.P.H. \\ (Assistant Pathologist, Bland Sutton Institute, Middlesex Hospital)
}

The reason for the compatibility or otherwise between two bloods was discovered by Landsteiner in I9oo. He found by a series of cross-testings with red corpuscles and blood sera from different individuals that all bloods could be divided into four chief groups according to the presence or absence from the corpuscles of one or other or both of two agglutinogens $\mathrm{A}$ and B. Two corresponding agglutinins $\alpha$ and $\beta$ (or anti-A and anti-B) may also be present in the serum and haemagglutination, and later haemolysis occurs wherever homologous agglutinin and agglutinogen come into contact with one another. Jansky in I907 in Europe and Moss in I909 in America classified the four blood groups by numbers, and their classifications are still occasionally met with. The various classifications and the usual agglutinin and agglutinogen content of the blood groups are given in Table I.

TABLE I

\begin{tabular}{|c|c|c|c|c|c|}
\hline \multicolumn{3}{|c|}{ Group } & \multirow{2}{*}{ Corpuscles } & \multirow{2}{*}{ Serum } & \multirow{2}{*}{ Formula } \\
\hline & Moss & Jansky & & & \\
\hline $\begin{array}{l}\mathrm{AB} \\
\mathrm{A} \\
\mathrm{B} \\
\mathrm{O}\end{array}$ & $\begin{array}{l}1 \\
2 \\
3 \\
4\end{array}$ & $\begin{array}{l}4 \\
2 \\
3 \\
1\end{array}$ & $\begin{array}{l}\text { Agglutinogens AB } \\
\text { Agglutinogen A } \\
\text { Agglutinogen B } \\
\text { Agglutinogen O }\end{array}$ & $\begin{array}{l}\text { Agglutinin o } \\
\text { Agglutinin } \beta \\
\text { Agglutinin } \alpha \\
\text { Agglutinins } \alpha+\beta\end{array}$ & $\begin{array}{l}\mathrm{AB} \text { o } \\
\mathrm{A} \beta \\
\mathrm{B} \alpha \\
\mathrm{O} \alpha \beta\end{array}$ \\
\hline
\end{tabular}

The reactions between the groups are given in Table II, a + indicating haemagglutination.

TABLE II

\begin{tabular}{|c|c|c|c|c|c|c|c|c|}
\hline$e^{2}$ & & & & & $\operatorname{Red} C$ & Group & & $\begin{array}{l}\text { Percentage of } \\
\text { Individuals }\end{array}$ \\
\hline & & & & $\mathrm{AB}(\mathrm{I})$ & $\mathrm{A}(2)$ & $\mathrm{B}(3)$ & $\mathrm{O}(4)$ & Group \\
\hline $\begin{array}{l}\text { AB (I), i.e., agglutinin o } \\
\text { A (2), i.e. agglutinin } \beta \quad \ldots \\
\text { B (3) i.e. agglutinin } \alpha \quad \ldots \\
\text { O (4), i.e. agglutinin } \alpha+\beta\end{array}$ & $\begin{array}{l}\ldots \\
\cdots \\
\cdots\end{array}$ & $\begin{array}{l}\cdots \\
\cdots \\
\cdots\end{array}$ & $\begin{array}{l}\cdots \\
\cdots \\
\cdots\end{array}$ & $\begin{array}{l}\mathrm{O} \\
+ \\
+ \\
+\end{array}$ & $\begin{array}{l}0 \\
0 \\
+ \\
+ \\
+\end{array}$ & $\begin{array}{l}\mathrm{O} \\
+ \\
\mathrm{O} \\
+\end{array}$ & $\begin{array}{l}\mathrm{O} \\
\mathrm{O} \\
\mathrm{O} \\
\mathrm{O}\end{array}$ & $\begin{array}{r}3 \\
42 \\
9 \\
46\end{array}$ \\
\hline
\end{tabular}

This table shows that Group $\mathrm{O}$ is a universal donor and should be able to give blood without ill-effects to any group, while Group $A B$ is a universal recipient and may be transfused from any group. In orientating possible blood donors it is usually sufficient to consider the agglutinogens of the donor's red cells in relation to the agglutinins of the recipient's plasma, the agglutinins of the donor's plasma being so greatly diluted and being so small quantitatively in relation to the mass of the recipient's red cells that agglutination and destruction of the recipients cells by the donor's plasma is exceedingly rare. Nevertheless a severe reaction from this cause may occur in the case of a donor with high titre agglutinins, and the chance is increased with a rapid massive transfusion in an exsanguinated patient. Hence it is always better to use a donor of the same group as the recipient rather than the so-called universal donor $\mathrm{O}$, who will have anti-A and anti-B agglutinins present in his plasma.

From the above tables it is evident that the blood group may be determined by means of the sera from group A and group B individuals. With such sera the corpuscles tested are agglutinated by both sera if they belong to $A B$, by group $B$ (anti-A) serum only if they belong to group A, by group A (anti-B) serum only if they belong to group B, and by neither serum if they are group $\mathrm{O}$. This method of testing the blood group is called the Indirect Test. As a cross-check on this indirect test a Direct Test must always be performed before a 
transfusion is given. In this the corpuscles of the donor are tested against the serum of the recipient. The techniques and difficulties in these tests will be discussed later.

A further investigation of the $\mathrm{A}$ agglutinogen has shown that group $\mathrm{A}$ corpuscles can be divided into two sub-groups $A_{1}$ and $A_{2}$, and similarly group. $A B$ into $A_{1} B$ and $A_{2} B$. The agglutinins which react with one or other of these sub-groups are as follows:

(I) $a$ which reacts with the sub-groups $A_{1}, A_{2}, A_{1} B$ and $A_{2} B$;

(2) $\alpha_{1}$ which reacts only with sub-groups $A_{1}$ and $A_{1} B$, but not with $A_{2}$ or $A_{2} B$; and

(3) anti-O (sometimes called $a_{2}$ ) which reacts with all $\mathrm{O}$ cells and 95 per cent of $\mathrm{A}_{2}$ cells.

Approximately 80 per cent of group $A$ bloods belong to the sub-group $A_{1}$, and 60 per cent of group $A B$ bloods to the sub-group $A_{1} B$; the remainder belong to the sub-groups $A_{2}$ and $A_{2} B$.

The recognition of the sub-groups modifies the concept of the complete safety of the universal donor and universal recipient. It is theoretically unsafe to give group $O$ cells to group $A_{1}$ and $\mathrm{A}_{1} \mathrm{~B}$ because the anti-O $\left(\alpha_{2}\right)$ agglutinin may be present in the sera-of the latter (see Table III). It is also theoretically unsafe for $A_{1} B$ to receive from $A_{2}$ or $A_{2} B$, or $A_{2} B$ from $A_{1}$ and $A_{1} B$ (Table III). However, these agglutinins associated with the sub-groups are usually present only in small amounts. For practical purposes the risk of sub-group incompatibility is negligible at a first transfusion, but after repeated transfusions a reaction due to this cause may very rarely occur if the donor's group or sub-group is different from that of the recipient. The reason is that the donor's cells may stimulate the formation of agglutinins against themselves in the recipient's serum, and these agglutinins may then react with the donor's cells at a later transfusion. Thus a group $\mathrm{O}$ donor may stimulate the formation of anti-O $\left(\alpha_{2}\right)$ agglutinins in a group $A_{1}, A_{1} B$ or $B$ recipient. Other possibilities can be worked out from Table III. The similar possible action of the $\mathrm{Rh}$ and allied factors will be discussed later. Similarly, during pregnancy and the puerperium, the agglutinogen of the foetal red cells, e.g. $O$, may pass through the placenta and stimulate the homologous agglutinins, e.g. anti-O $\left(\alpha_{2}\right)$, which may react with the donor's cells at a first transfusion.

In actual practice reactions due to these causes are extremely rare, even after repeated transfusions and pregnancies.

There is a much more important source of danger, however, in dealing with the sub-groups, and that is found in the preliminary blood-grouping tests. Group $\mathrm{A}_{2}$ cells are relatively insensi-ce tive to any but very high titre anti-A serum, and this is still more marked in group $\mathrm{A}_{2} \mathrm{~B}$ because the sensitivity of $\mathrm{A}_{2}$ factor is still further depressed when in combination with $\mathrm{B}$ (Taylor, et al., I940). Thus group $\mathrm{A}_{2}$ is liable to be interpreted as group $\mathrm{O}$ and $\mathrm{A}_{2} \mathrm{~B}$ as $\mathrm{B}$. Direct cross-matching does not necessarily avoid the error because the cause, the insensitivity of the cells, is not eliminated. Difficulties due to this cause may be avoided by using for the indirect grouping test, only high titre $B$ (anti-A) sera, which are known to react well to the sub-groups $A_{2}$ and $\mathrm{A}_{2} \mathrm{~B}$, but which do not contain the anti-O $\left(\alpha_{2}\right)$ agglutinin. The various possibilities of agglutinogen and agglutinin content of the blood in the various groups are summarised in Table III. (Modified from the Medical Research Council's War Memorandum No. 9).

TABLE III

\begin{tabular}{|c|c|c|c|}
\hline Group or Subgroup & Reacts with Agglutinins & $\begin{array}{l}\text { Agglutinins normally } \\
\text { present in the serum }\end{array}$ & $\begin{array}{l}\text { Aglutinins which may be } \\
\text { present }\end{array}$ \\
\hline $\mathbf{A}_{1}$ & $\alpha$ and $\alpha_{1}$ & Anti-B $(\beta)$ & $\begin{array}{l}\text { Anti-O }\left(\alpha_{2}\right) \text { very rare. Reacts } \\
\text { with } 9,5 \text { per cent } A_{2} \text { and with } \\
\text { all O cells }\end{array}$ \\
\hline $\mathrm{A}_{2}$ & $\begin{array}{c}\alpha \text { (always) and Anti-O }\left(\alpha_{2}\right) \\
(95 \text { per cent of cases) }\end{array}$ & Anti-B $(\beta)$ & $\begin{array}{l}\alpha_{1}(1-2 \text { per cent }) \text { reacts with } \\
A_{1} \text { and } A_{1} B \text { cells }\end{array}$ \\
\hline $\mathrm{A}_{1} \mathrm{~B}$ & $\alpha, \alpha_{1}$ and $\beta$ & None & $\begin{array}{l}\text { Anti-O }\left(\boldsymbol{\alpha}_{2}\right) \text { very rare. Reacts } \\
\text { with } 95 \text { per cent of } \mathrm{A}_{2} \text { and } \\
\text { with all O cells }\end{array}$ \\
\hline $\mathrm{A}_{2} \mathrm{~B}$ & $\alpha$ and $\beta$ & None & $\begin{array}{l}\alpha_{1}(25-30 \text { per cent) reacts with } \\
\mathrm{A}_{1} \text { and } \mathrm{A}_{1} \mathrm{~B} \text { cells }\end{array}$ \\
\hline B & $\beta$ & Anti-A $\left(\alpha\right.$ and $\left.\alpha_{1}\right)$ & $\begin{array}{l}\text { Anti-O }\left(\alpha_{2}\right) \text { very rare. Reacts } \\
\text { with } 95 \text { per cent } \mathrm{A}_{2} \text { cells and } \\
\text { with all } \mathrm{O} \text { cells }\end{array}$ \\
\hline $\mathrm{O}$ & Anti-O $\left(a_{2}\right)$ & $\begin{array}{l}\text { Anti-A }\left(\alpha \text { and } \alpha_{1}\right) \text { and } \\
\text { Anti-B }(\beta)\end{array}$ & None \\
\hline
\end{tabular}




\section{The Indirect Grouping Test}

The slide or tile method is the most useful method in general practice, although the tube 3 method (see Direct Matching) is more accurate and should be used in all cases of difficulty. $\stackrel{\mathbb{Q}}{\stackrel{2}{ }}$ A glass slide, or better, a white opal glass tile, is divided into two sections by a scratch or grease.. pencil mark and the sections labelled $\mathrm{A}$ and $\mathrm{B}$. On the part marked $\mathrm{A}$, one drop of anti-A $\Rightarrow$ serum is placed, and on the other part one drop of anti-B serum. A separate pipette is used for each serum. To each drop is added, with a pipette or loop, one drop of approximately $3-5$ 응 per cent suspension of the red cells to be tested diluted in normal saline, or 3 per cent citrate $\frac{\bar{\sigma}}{\overline{0}}$. saline. The use of diluted red cells is absolutely essential if false positive reactions are to be $\vec{\varnothing}$ avoided. The slides are rocked slowly to and fro intermittently and examined after Io minutes. The agglutination is easily seen with the naked eye, but may be confirmed under the low power of the microscope. As an extra check the serum of the blood examined may also be tested for $\overrightarrow{0}$ its agglutinin content in a similar manner (Table I). In this case double the quantity of the $\overrightarrow{\vec{H}}$ unknown serum should be added to one drop of each of known diluted $\mathrm{A}$ and $\mathrm{B}$ cells, and the preparation read microscopically.

\section{The Direct Matching .Test}

The direct test must always be carried out except possibly in an extreme emergency, and $\vec{\oplus}$ in such cases group $O$ blood should be given. This test does not replace the indirect test which $\vec{\omega}$ should always be used for both donor and recipient. The tile method can be used with diluted $ᄋ$ donor's cells and twice the quantity of the recipient's serum, but it is preferable to use the more delicate tube method, since atypical agglutinins which may be present in the serum of sick persons are often of feeble agglutinating power.

Small clean test tubes approximately $7 \mathrm{~mm}$. diameter are used. Two volumes of serum, 竞 one volume of normal saline and one volume of 3-.5 per cent donor's red cells in saline are added $\overrightarrow{0}$ to the tube and mixed by shaking. Two control tubes should be put up, the first with on 8 volume of diluted donor's cells and three volumes of saline, and the second with one volume: of diluted known group $\mathrm{C}$ cells, two volumes of serum and one volume of normal saline. The result is read under the low power of the microscope after one hour at $37^{\circ} \mathrm{C}$. or two hours at room temperature. The reaction can be quickened by centrifuging the tubes for one minute at low speed after half-an-hour in the incuhator, gently shaking and then examining.

\section{Difficulties in the interpretation of haemagglutination tests}

If high titre sera are used, and if the anti-A serum used is active against $A_{2}$ and $A_{2} B$ cells (vide supra), the chief difficulties are those due to the presence of:-

I. Panagglutinins.

2. Pseudo-agglutination or rouleaux formation.

3. Non-specific cold agglutinins.

4. Intra- and sub-group agglutinins.

\section{Bacterial panagglutination.}

Thomsen (1927) accidentally discovered that certain non-pathogenic bacteria, chiefly of $\frac{\text { D }}{\stackrel{2}{.}}$ the diphtheroid group, were capable of altering the red cells so that they became panagglutin- N able, i.e. could be agglutinated by sera of all four groups. These bacteria may contaminate the glassware or skin and so contaminate the red cells. Friedenreich (1930) found the phenomenon in 30 cases of 536 samples of blood obtained for the Wassermann test, after storage for four days. Davidsohn and Toharsky (1942) isolated from contaminated typing serum, a non-pathogenic bacterium, C. hektoenii which imparted to the serum or plasma, panagglutinating properties against fresh red cells. They called the' phenomenon bacteriogenic haemagglutination. As the bacteria can grow at $4^{\circ} \mathrm{C}$., storage at this temperature is not sufficient for prevention. Antiseptics added to the serum, however, are effective. Inclusion of group $\mathrm{O}$ cells as a control in a test series will prevent error from bacteriogenic agglutinins, while the use of fresh cells will exclude the Thomsen phenomenon. 


\section{Pseudo-agglutination or rouleaux formation.}

This phenomenon is noticed especially in slide preparations if there is delay in reading the reaction, and occurs chiefly with the sera of patients suffering from septic conditions. It is more common when the test is carried out at $37^{\circ} \mathrm{C}$. than at room or lower temperatures. Failure to dilute the blood used with saline is the most common cause, and rouleaux formation seldom gives trouble with the technique described above. The phenomenon is non-specific, and is not due to an absorbable agglutinin. It may be suspected when, in carrying out the direct matching test, it is found that the red cells of several theoretically compatible donors are apparently agglutinated. The use of group $\mathrm{O}$ cells as a control has already been described. Microscopic examination of the preparations usually show characteristic rouleaux, but distinction from true agglutination may be difficult. Usually tapping of the preparation will cause disappearance of the rouleaux. However, for definite exclusion the tests should be repeated with an added volume of normal saline and at room temperature or in the refrigerator.

\section{Cold agglutinins.}

The ordinary isoagglutinins anti-A and anti-B react well at cool or body temperature. Certain other agglutinins which may occur in normal sera act well in the cold, but less readily at room temperature and, exceedingly rarely, at body temperature. These are called cold agglutinins. Non-specific cold agglutinins will agglutinate all red cells irrespective of group, and also, in the cold, the cells of the person in whose serum they occur. Hence they are often called auto-agglutinins.

If they are active at room temperature they will cause agglutination of the red cells of the person being grouped by the technique given above, and so give a false diagnosis of group $A B$, Confusion may be avoided by washing the red cells with saline at $37^{\circ} \mathrm{C}$. to get rid of the agglutinins and, by checking the group by testing for iso-agglutinins anti-A or anti-B in the serum of the person grouped. The simplest method, however, is to carry out the test at $37^{\circ} \mathrm{C}$., having raised the diluted cells and sera to that temperature before mixing.

Also, in carrying out the direct matching test at room temperature, if cold agglutinins are present the patient's serum may be found to agglutinate all donors whether theoretically com-cot patible or not, and thus the $\mathrm{O}$ control cells will be agglutinated. The direct test should then $\rightleftharpoons$ be repeated at $37^{\circ} \mathrm{C}$.

\section{Intra-group and sub-group agglutinins.}

The agglutinins of the subgroups, $a_{1}$, and anti-O $\left(a_{2}\right)$ may cause agglutination as described above. Agglutinins against the red cell agglutinogens $R h, M$ and $P$ (no case of spontaneous agglutinins against the $\mathrm{N}$ factor has yet been reported) may also exceedingly rarely occur in a recipient's serum, and then usually after repeated blood transfusions or during pregnancy where the mother may be immunised by a child with a different red cell agglutinogen content from her own. These agglutinins usually (except possibly the $\mathrm{Rh}$ agglutinin) act better in the cold, but may also react at higher temperatures and then cause difficulties. They should be suspected where only some theoretically compatible groups show agglutination in the direct matching test. It is because of these intra-group agglutinins that it is recommended that the direct test should be carried out where possible by the more delicate tube method.

If there is any doubt about the presence of incompatible agglutinins in the recipient's serum (and the presence of non-specific cold agglutinins may. sometimes mask a weak intra-group agglutination), then a biological test for compatibility should be carried out before transfusion if time allows.

Wiener, Silvermann and Aronson (I942) recommend the following technique:-..

One hundred cc. of the prospective donor's blood are mixed with ro cc. of 3.8 per cent dihydric sodium citrate solution. Io cc. of blood are drawn from the patient and divided between two tubes, one empty and the other containing I cc. of the citrate solution. Through the same needle 50 cc. of the donor's blood are injected by syringe. After one hour, ro cc. of blood are drawn from the patient and treated in the same way as the pre-transfusion sample. The citrated blood samples are centrifuged at once and the colour of the plasma in the two tubes compared. The serums from the clotted blood samples are later separated, after the blood has firmly clotted, this serving as a check on the results of the tests with the citrated blood samples. 
The purpose of the duplicate test is to avoid the occurrence of an artefact due to traumatisation of the red blood cells, particularly when separating the clot from the wall of the tube. Naturally, care must be taken that the needles and syringes used for the test are perfectly dry.

If there is no change in the appearance of the patient's plasma, and the need for blood is urgent; one can then proceed with the transfusion of larger amounts of blood from the same donor. When time permits, however, it is preferable to inject another test dose of $50 \mathrm{cc}$. of the donor's blood and to draw a third sample of blood after an additional hour. In this way more reliable results can be obtained and the reaction in positive cases is more striking. In positive reactions, one hour after the test injection of $50 \mathrm{cc}$. of blood, the patient may have a severe chill and rise in temperature, but the clinical symptoms may be quite mild, and occasionally they may be entirely absent. More reliance is to be placed on the appearance of the patient's plasma, which will show a distinct rise in the icteric index as compared with the pre-transfusion sample. The donor's blood used for the biological test should be fresh; if only bank blood is available, no sample more than three days old should be used. The reason for this is that blood stored for periods longer than 7 to io days, even though apparently intact when transfused, often breaks down rapidly in the patient's circulation. In this way a positive biological reaction might be obtained even with serologically compatible blood.

\title{
SUMMARY
}

The practical points in this short review may be summarised as follows. Before a transfusion is given the direct and indirect blood matching tests should be carried out using an exact technique. Particular care should be taken in direct matching recipients who have had previous transfusion, or who are or have recently been pregnant. Where there is any doubt as to the presence of atypical agglutinins in the recipient's serum, a biological test should be a routine preliminary to transfusion.

\section{BIBLIOGRAPHY}

DAVIDSON, I., and TOHARSKY, B. (1942), J. immunol, 43, 213.

FRIEDENRICH, V. (I930). The Thomsen haemagglutination phenomenon. Levin and Munksgaard, Copenhagen.

TAYLOR, G. L., RACE, R. R., PRIOR, A. M., and IKIN, E. W. (I940). Brit. Med. J., 1, 297.

WIENER, A. S., SILVERMAN, I. J., and ARONSON, W. (1942). Amer. J. Clin. Path. 12, 24 r.

\section{THE APPLICATION OF PRESENT KNOWLEDGE ABOUT THE RH FACTOR}

\author{
By P. L. MOLLISON, M.B., M.R.C.P.
}

\section{A. A BRIEF OUtline OF KNOWN facts AbOUT Rh Agglutinogen}

The facts about the $\mathrm{Rh}$ agglutinogen are at first sight easy to understand. 85 per cent of human beings (whites) are $\mathrm{Rh}$ positive (that is their erythrocytes contain the $\mathrm{Rh}$ agglutinogen): I5 per cent are Rh negative. This newly recognised grouping is independent of the four main blood groups and differs from the latter system in one very important respect, namely, in that persons whose erythrocytes lack the $\mathrm{Rh}$ agglutinogen do not normally have the corresponding anti-Rh agglutinin in their serum. It will be recalled that, by contrast, in the four main blood groups lack of the A or B agglutinogens from the erythrocytes is always accompanied by the presence of the corresponding anti-A or anti-B agglutinins in the serum.

$\mathrm{Rh}$ negative persons can, however, form anti-Rh agglutinins under either of two circumstances, and in this fact lies the importance of the $\mathrm{Rh}$ agglutinogen. These circumstances are-

(i) (in persons of either sex) after the transfusion of $\mathrm{Rh}$ positive blood;

(ii) (in women) during pregnancy, when the foetus is $\mathrm{Rh}$ positive (the $\mathrm{Rh}$ agglutinogen having been inherited from the father). 